\title{
Proteolytic cleavage of Ras GTPase-activating protein during apoptosis
}

\author{
Long-Ping Wen ${ }^{1}$, Kamyar Madani ${ }^{1}$, George A. Martin ${ }^{2}$ and \\ Glenn D. Rosen ${ }^{1,3}$ \\ 1 Department of Pulmonary and Critical Care Medicine, Stanford University, \\ Stanford, California 94305-5236, USA \\ 2 Onyx Pharmaceuticals, Richmond, California 94806, USA \\ ${ }^{3}$ corresponding author: Glenn D. Rosen, M.D., Stanford University Medical \\ Center, Pulmonary and Critical Care Medicine, 300 Pasteur Dr., Stanford, \\ California 94305-5236; tel: (650) 725-9536; fax: (650) 725-5489; \\ email: grosen@leland.stanford.edu
}

Received 18.12.97; revised 21.3.98; accepted 8.5.98

Edited by J.C. Reed

\begin{abstract}
p120-ras GTPase-activating protein (rasGAP) associates with Ras and negatively regulates Ras signaling by stimulating the intrinsic rate of Ras GTPase activity. rasGAP also associates with other cellular signaling proteins which suggest that rasGAP may play a role in coordinating other signal transduction pathways. Disruption of rasGAP in vivo results in extensive apoptosis. Fas-mediated apoptosis results in the activation of caspases that cleave cellular substrates which are important for maintaining cytoplasmic and nuclear integrity. We show here that rasGAP is proteolytically cleaved by caspases early in Fas-induced apoptosis of Jurkat cells. rasGAP was also cleaved by DNA-damaging chemotherapeutic agents and TNF-related apoptosis inducing ligand (TRAIL), also known as Apo2L. Based on the size of the products generated by cleavage of deletion mutants of rasGAP we predict that cleavage of rasGAP occurs in the hydrophobic region and between the $\mathrm{SH}$ (2) and ras-p21 interacting domain which would leave an intact ras-p21 interacting domain. Interestingly, cleavage of rasGAP in vitro enhanced rasGAP hydrolysis activity. Our results demonstrate that diverse apoptotic stimuli cause caspase-mediated cleavage of rasGAP early in apoptosis.
\end{abstract}

Keywords: programmed cell death; caspase; Ras; Fas

Abbreviations: TNF, tumor necrosis factor; GTP, guanosine triphosphate; GAPs, GTPase-activating proteins; NF1, type 1 neurofibromatosis; ICE, interleukin-1 $\beta$ converting enzyme; PARP, poly-ADP-ribose polymerase; TRAIL, TNF-related apoptosis inducing ligand; FAK, focal adhesion kinase

\section{Introduction}

Apoptosis is a physiological process that is important for the elimination of transformed cells, for organization of develop- ing tissues and for immune regulation (reviewed in Steller, 1995). Fas/Apo-1 is a member of the tumor necrosis factor (TNF) receptor family that induces apoptosis in Fas ligandexpressing cells (Itoh et al, 1991). Fas has been shown to play an important role in modulation of the immune response. A recent study has demonstrated that activation of the Fas pathway induces activation of the Ras signaling pathway and that inhibition of Ras inhibits Fas-induced apoptosis (Gulbins et al, 1995). Additional support for a role Ras activation in Fas-induced apoptosis comes from a study which showed that Fas receptor triggering causes Ras-dependent activation of the small G-proteins Rac 1 and Rac 2 and inhibition of Ras, Rac 1 or Rac 2 inhibits Fas-induced apoptosis (Gulbins et al, 1996).

Ras is activated by the exchange of bound guanosine 5'-diphosphate (GDP) for guanosine triphosphate (GTP) (reviewed in McCormick, 1994). In the GTP-bound active state, Ras-GTP interacts with and activates downstream targets. GTPase-activating proteins (GAPs) inactivate Ras by accelerating the slow intrinsic rate of GTP hydrolysis (Trahey et al, 1988; Martin et al, 1990). Five mammalian GAP's for Ras have been described which include p120rasGAP (rasGAP), the prototype of this class and neurofibromin, the product of the type I neurofibromatosis (NF1) gene (reviewed in Bollag and McCormick, 1991). Recently, Henkemeyer et al, demonstrated that disruption of rasGAP in vivo results in massive neuronal cell death (Henkemeyer et al, 1995). Their findings support previous observations that, without inhibiting Ras signaling, neuralderived PC12 cells make an abortive attempt to enter the cell cycle and undergo apoptosis (Ferrari and Greene, 1994). It is also possible that rasGAP may regulate specific apoptosis signaling pathways. For example, it was recently shown that R-Ras, a Ras-related protein which promotes apoptosis in some cells interacts with Bcl2 (Wang et al, 1995). Although the mechanism by which inactivation of rasGAP promotes apoptosis is as yet unknown, the study by Henkenmeyer et al (1995) supports a role rasGAP in controlling apoptotic signaling pathways in vivo.

It is clear that mammalian cysteine proteases (now designated caspases) related to the Caenorhabditis elegans cell death gene CED-3 are the effectors of the apoptotic signaling pathway triggered by members of the tumor necrosis factor (TNF) family (reviewed in Dixit, 1996). Activation of interleukin-1 $\beta$ (ICE)-related proteases by Fas results in the cleavage of substrates that are thought to play a role in maintaining cytoplasmic and nuclear integrity such as lamin A, poly-ADP-ribose polymerase (PARP), $\alpha$ Fodrin, sterol regulatory element-binding proteins, the 70 $\mathrm{kDa}$ protein component of the U1 small nuclear ribonucleoprotein, the retinoblastoma tumor suppresser gene product, product kinase $\mathrm{C} \delta$, DNA-dependent protein kinase and the 
GDP dissociation inhibitor D4-GDI (Song et al, 1996; $\mathrm{Na}$ et al, 1996; Waterhouse et al, 1996; Casciola-Rosen, 1996; Emoto et al, 1995; Wang et al, 1996; Brancolini et al, 1995; Lazebnik et al, 1994).

We have recently shown that apoptosis induced by Fas and TNF-related apoptosis inducing ligand (TRAIL), also known as Apo2L, cause caspase-mediated cleavage of focal adhesion kinase (FAK) in both suspension and adherent cell lines (Wen et al, 1997). Here we show that activation of the Fas pathway also induces caspasemediated cleavage of p120/rasGAP (rasGAP). Cleavage of rasGAP occurred early in apoptosis at approximately the same time as PARP and FAK cleavage. We also observed that rasGAP is cleaved by other apoptotic stimuli such as TRAIL and doxorubicin. Cleavage of rasGAP in vitro enhanced rasGAP hydrolysis activity suggesting that cleavage of rasGAP during apoptosis in vivo may downregulate Ras activity.

\section{Results and Discussion}

\section{Fas-induced cleavage of rasGAP}

Disruption of rasGAP causes apoptosis in vivo (Henkemeyer et al, 1995). We hypothesized, therefore, that rasGAP may be cleaved during apoptosis. We observed that rasGAP is cleaved beginning at $1 \mathrm{~h}$ after the addition of a crosslinking activating Fas antibody, a time that coincides with PARP and FAK cleavage in Jurkat cells (Figure 1A) (Wen et al, 1997). Ras GAP was cleaved into two fragments of approximately $55 \mathrm{kD}$ and $37 \mathrm{kDa}$ (Figure 1A). The $55 \mathrm{kD}$ fragment (I) was observed at $1 \mathrm{~h}$ after Fas activation followed at $2 \mathrm{~h}$ by the appearance of the $37 \mathrm{kD}$ fragment (II). The commercial antibody that was used to detect rasGAP cleavage in vivo is a monoclonal antibody but its epitope is unknown. The $\mathrm{SH} 3$ domain of rasGAP, however, is the most antigenic and our in vitro cleavage data suggests that the antibody recognizes the $\mathrm{SH} 3$ domain. Cleavage of rasGAP was almost completely inhibited by the tetrapeptide caspase inhibitor DEVD-CHO $(40 \mu \mathrm{M})$ and to a lesser extent by YVAD-CHO $(40 \mu \mathrm{M})$ (Figure 1A). Activation of the Fas pathway in other cell lines such as $\mathrm{H} 460$ non-small cell lung cancer cells and MCF-7 breast cancer cells also induced cleavage of rasGAP (data not shown). Additionally, other stimuli which induce caspase-mediated apoptosis such as the chemotherapeutic drug doxorubicin and TNF-related apoptosis-inducing ligand (TRAIL), also known as Apo2L, induced rasGAP cleavage (Figure 1B). Taxol, however, did not induce rasGAP cleavage (Figure 1B). Doxorubicin, taxol and TRAIL/Apo2L decreased $\mathrm{H} 460$ viability by more than $80 \%$ (data not shown). We also examined if the rasGAPassociated protein p62 was cleaved during apoptosis but Fas-induced apoptosis did not induce cleavage of p62 (data not shown). These data show that cleavage of rasGAP is mediated by a DEVD-inhibitable caspase(s) such as caspase-3 and caspase-7 and that cleavage of rasGAP is induced by diverse apoptotic stimuli and in different cell lines.
$\mathbf{A}$

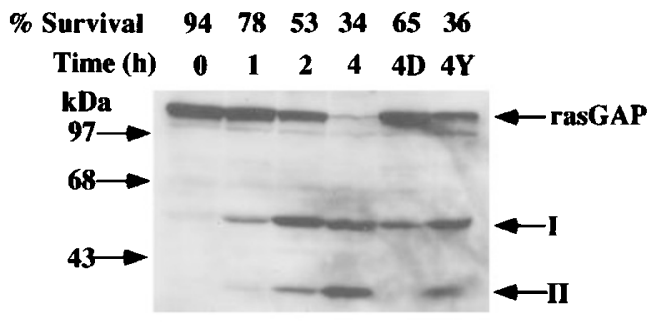

B

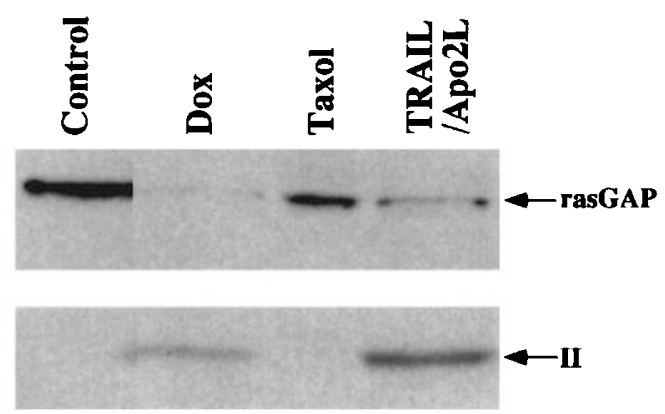

Figure 1 Cleavage of rasGAP during apoptosis. In (A) Jurkat cells were treated with the $\mathrm{CH}-11$ anti-Fas $\mathrm{mAB}(100 \mathrm{ng} / \mathrm{ml})$ and harvested for immunoblot analysis at the times shown. The blot was probed with a commercial anti-rasGAP mAb (Santa Cruz Biotechnology, Santa Cruz, CA). Intact rasGAP migrates at $115-120 \mathrm{kDa}$. A rasGAP cleavage product of approximately $55 \mathrm{kDa}(\mathrm{I})$ appears $1 \mathrm{~h}$ after the addition of Fas which is followed by the appearance of a second cleavage product of approximately $37 \mathrm{kDa}$ (II) at $2 \mathrm{~h}$. The caspase inhibitors DEVD-CHO $(40 \mu \mathrm{M})$ (lane 4D) and YVAD-CHO $(40 \mu \mathrm{M})$ (lane $4 \mathrm{Y})$ were added to Jurkat cells 1 prior to anti-Fas. In (B) H460 non-small cell lung cancer cells were treated with TRAIL/Apo2L $(100 \mathrm{ng} / \mathrm{ml})$, doxorubicin (Dox) $(2 \mu \mathrm{M})$ or taxol $(100 \mathrm{~nm})$ and harvested for immunoblot analysis with an anti rasGAP $\mathrm{mAB} 48 \mathrm{~h}$ later

\section{rasGAP is cleaved in vitro by caspase-3 and caspase-7}

In order to determine which caspase(s) mediates rasGAP cleavage we examined the sensitivity of rasGAP to different caspases in vitro. Incubation of purified rasGAP with $100 \mathrm{ng}$ of caspase-3 or caspase-7 resulted in complete cleavage of rasGAP into the $37 \mathrm{kDa}$ fragment with only a small amount of the $55 \mathrm{kDa}$ fragment (Figure 2A). Caspase- 6 and caspase- 8 alone had limited activity against rasGAP but they completely cleaved rasGAP in the presence of naive extract (Figure $2 \mathrm{~A}$ and $B$ ). These data are in agreement with previous studies which show that caspase- 6 and caspase- 8 activate other caspases in naive extract such as caspase- 3 and caspase-7 (Srinivasula et al, 1996; Chinnaiyan et al, 1996).

We then compared the sensitivity of rasGAP to caspase3 versus caspase-7 in vitro. We have previously shown that FAK is more sensitive to cleavage by caspase-7 in vitro (Wen et al, 1997). These purified caspases are equally active against a defined substrate (see Materials and Methods). Incubation of purified rasGAP with increasing 
A
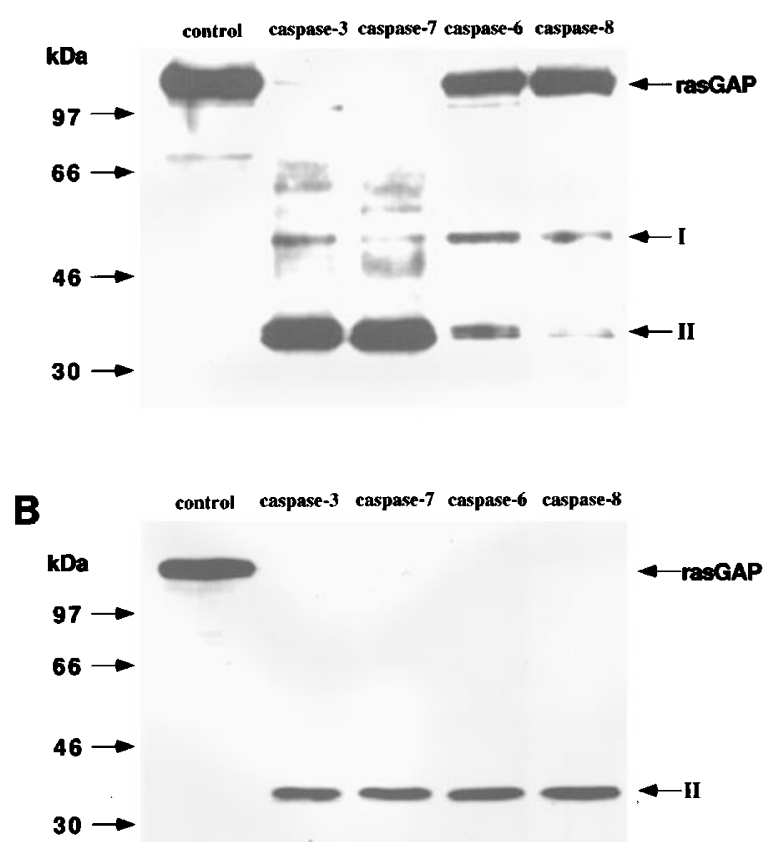

Figure 2 Caspase-3 (CPP32, YAMA, Apopain) and caspase-7 (Mch3, ICELAP3, CMH-1) mediate cleavage of rasGAP in vitro. $200 \mathrm{ng}$ of purified rasGAP was incubated with $200 \mathrm{ng}$ of caspase-3, caspase-7, or caspase- 6 or $400 \mathrm{ng}$ of caspase-8 in the absence (A) or presence (B) of Jurkat cell extract $(50 \mu \mathrm{g})$ for $1 \mathrm{~h}$ at $37^{\circ} \mathrm{C}$. The samples were then processed for immunoblot analysis with the rasGAP commercial $\mathrm{mAB}$. Caspase-3 and caspase-7 generate predominantly the $37 \mathrm{kDa}$ second rasGAP cleavage product (II) (A and $\mathbf{B}$ ) and caspase- 6 and caspase- 8 cleave rasGAP completely only in the presence of naive extract $(\mathbf{B})$

concentrations of caspase- 3 resulted in the generation of the $55 \mathrm{kDa}$ and $37 \mathrm{kDa}$ fragments and a small amount of a newly observed fragment of approximately $100 \mathrm{kDa}$ (Figure 3). Caspase-7 generated predominantly the $55 \mathrm{kDa}$ fragment with less of the $37 \mathrm{kDa}$ fragment than caspase3 and no $100 \mathrm{kDa}$ fragment (Figure 3). These data suggest the cleavage of rasGAP, unlike FAK cleavage, is more sensitive to caspase- 3 than caspase- 7 and also that the caspase-3 likely generates the $37 \mathrm{kDa}$ fragment in vivo.

\section{Mapping of the rasGAP cleavage sites}

We have observed that rasGAP is cleaved into two fragments in vivo and that cleavage is inhibited by the tetrapeptide DEVD but the epitope recognized by the commercial $\mathrm{mAB}$ is unknown. DEVD-inhibitable caspases such as caspase-3 and caspase-7 preferentially cleave substrates at DXXD (Nicholson et al, 1995; Talanian et al, 1997). In order to better define the rasGAP cleavage sites we used an antibody that recognizes a KT3 epitope tag which is present on the carboxyl terminal end of the purified rasGAP. Incubation of purified full length rasGAP with caspase-3 followed by immunoblotting with the anti-KT3 antibody detected a fragment of approximately $66 \mathrm{kDa}$ (Figure 4A). A small amount of a $97 \mathrm{kDa}$

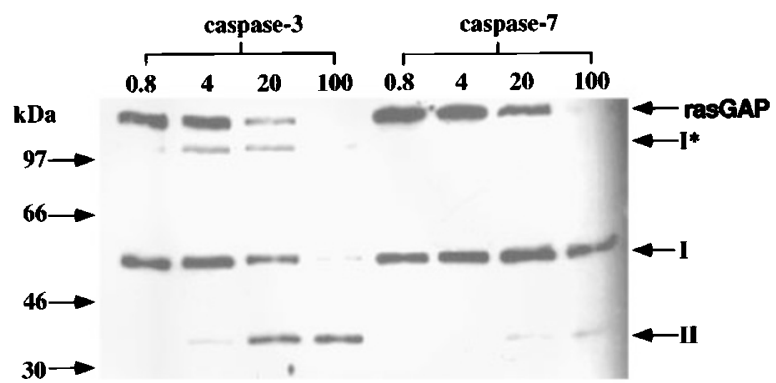

Figure 3 The $37 \mathrm{kDa}$ rasGAP cleavage product (II) is preferentially generated by caspase- 3 in vitro. $200 \mathrm{ng}$ of purified rasGAP was incubated with the indicated amounts of purified caspase- 3 or caspase- 7 for $1 \mathrm{~h}$ at $37^{\circ} \mathrm{C}$ and then processed for immunoblot analysis with the rasGAP mAb. Caspase-3 generates more of the second rasGAP cleavage product (II) then caspase-7 at the same caspase concentrations. Caspase- 3 also generates a new cleavage product of approximately $100 \mathrm{kDa}\left(I^{*}\right)$

$\mathbf{A}$

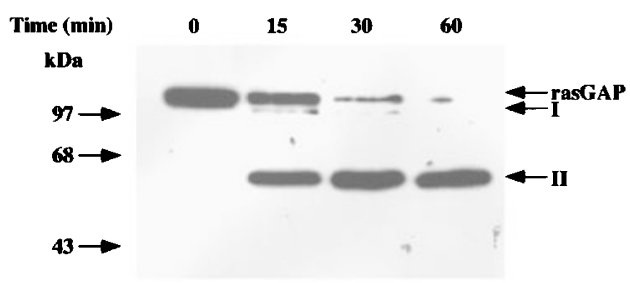

B

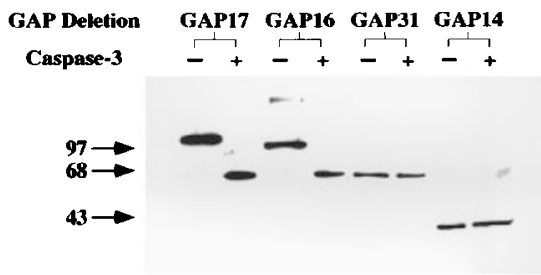

C

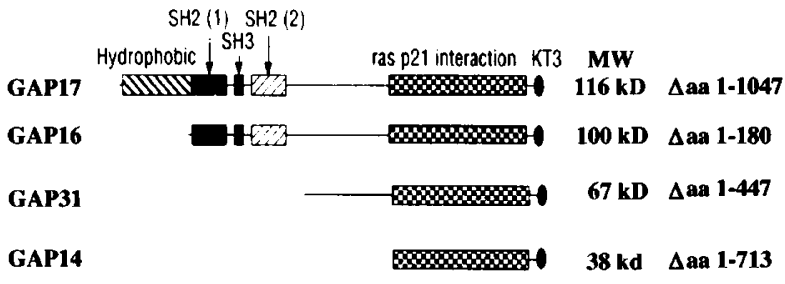

Figure 4 Mapping of rasGAP cleavage sites. In (A) $200 \mathrm{ng}$ of purified rasGAP was incubated with caspase-3 $(100 \mathrm{ng})$ for the indicated times at $37^{\circ} \mathrm{C}$ and then processed for immunoblot analysis with an anti-KT3 antibody. KT3 is an epitope tag at the carboxyl terminus of rasGAP. The $\alpha \mathrm{KT} 3$ antibody detects cleavage products of approximately $97 \mathrm{kDa}$ (I) and $66 \mathrm{kDa}$ (II). In (B) deletion mutants of rasGAP were incubated with caspase-3 as described in (A) and then processed for immunoblot analysis with the anti-KT3 antibody. In (C) a description of the different deletion mutants is shown

fragment was also detected at $30^{\prime}$ after the addition of caspase-3. To more precisely map the putative cleavage sites in rasGAP we examined the pattern of rasGAP cleavage 
using deletion mutants of rasGAP (Martin et al, 1992) which also contain the KT3 epitope at the carboxyl terminus (Figure $4 \mathrm{~B}$ and $\mathrm{C}$ ). Cleavage of GAP16 generated a fragment which migrated at the same position as cleavage of full length rasGAP (Figure 4B and $\mathrm{C}$ ). The migration of GAP 31 and GAP14 was unaffected by cleavage with caspase-3 (Figure $4 \mathrm{~B}$ and $\mathrm{C}$ ). On the basis of the size of these rasGAP cleavage products we predict that the first cleavage occurs after the P1 at amino acid 157 in the sequence DEGD/S (I) and the second cleavage occurs after the $\mathrm{P} 1$ at amino acid 459 in the sequence DTVD/G (II) (see Figure 5 for schematic of rasGAP cleavage). Cleavage of rasGAP at these sites would, therefore, not disrupt GAP14 and it would cleave only 12 amino acids off GAP31 which accounts for cleaved GAP 14 and GAP31 migrating at the same MW as uncleaved GAP14 and GAP31. The cleavage site after the aspartate at amino acid 157 is in the hydrophobic region of rasGAP and the cleavage site after the aspartate at amino acid 459 is between the second $\mathrm{SH} 2$ domain of rasGAP and the ras-p21 interacting domain (Figure 5). This pattern of cleavage would leave an intact ras p21-interacting domain and map the epitope recognized by the commercial antibody to the $\mathrm{SH} 3$ domain in rasGAP.

\section{Cleavage of rasGAP by caspase-3 in vitro enhances rasGAP hydrolysis activity}

We then examined if cleavage of rasGAP affects rasGAP hydrolysis activity, i.e., the conversion of rasGTP to rasGDP. rasGAP activity was difficult to quantify in apoptotic Jurkat cell extracts so that we examined the effect of caspase-3mediated cleavage of rasGAP on rasGAP activity in vitro. Increasing doses of purified rasGAP were incubated with caspase-3 and then followed by a filter binding rasGAP activity assay. One half of the sample was analyzed by immunoblotting with a rasGAP $\mathrm{mAB}$ and confirmed that rasGAP is cleaved (data not shown). At the lowest concentration of rasGAP (125 ng) cleaved rasGAP converted $92 \%$ of Ras-GTP to Ras-GDP but uncleaved rasGAP only converted $71 \%$ of Ras-GTP to Ras-GDP (Figure 6). There was no significant difference in rasGAP activity between cleaved and uncleaved rasGAP with higher concentrations of rasGAP (Figure 6). Approximately $60 \%$ of Ras-GTP is converted to Ras-GDP at $10^{\prime}$ in the absence of
rasGAP which reflects the intrinsic rate of Ras hydrolysis (Figure 6). Our data suggests that cleaved rasGAP is more active than uncleaved rasGAP in converting active Ras to inactive Ras. We predict that cleavage of rasGAP generates an intact ras p21-interacting domain (see Figure 5) but isolates this domain from the remainder of rasGAP. It is possible, therefore, that the other domains in rasGAP suppress rasGAP activity in dividing cells. Cleavage of rasGAP in apoptotic cells may inhibit Ras activity and thereby downregulate signals that promote cell growth.

rasGAP is an important negative regulator of Ras activity and we have observed that cleavage of rasGAP enhances the hydrolysis of active Ras to inactive Ras in vitro. Recent studies also suggest that rasGAP possesses other important biological functions. rasGAP, for example, associates through its $\mathrm{SH} 2$ domains with autophosphorylated receptors and two intracellular proteins, p62 and p190 (Ellis et al, 1990; Kazlauskas et al, 1990; Moran et al, 1991). p190 contains a rasGAP domain that is specific for Rho-related GTPases, which regulate the formation of actin stress fibers and focal adhesions (Settleman et al, 1992; Ridley and Hall, 1992). A recent study described a new

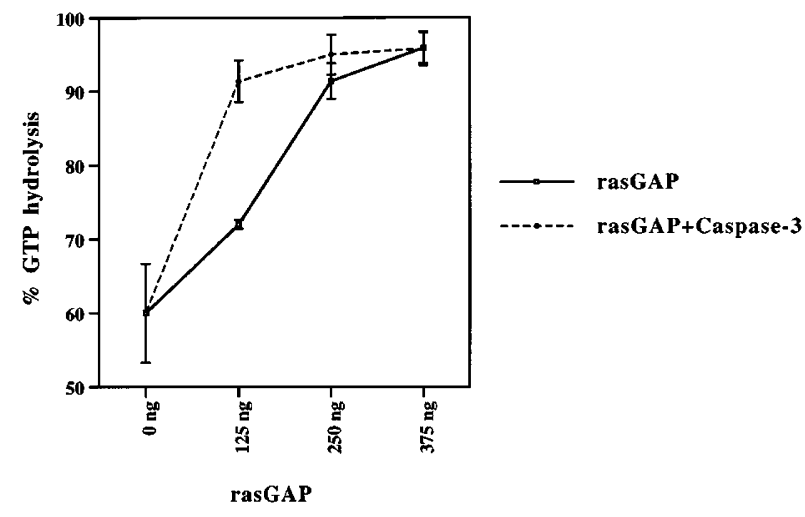

Figure 6 Cleavage of rasGAP in vitro enhances rasGAP activity. Varying concentrations of rasGAP were incubated with caspase-3 $(200 \mathrm{ng})$ for $10 \mathrm{~min}$ followed by analysis of rasGAP activity with a filter binding assay. \% GTP hydrolysis was calculated as $1-($ GTP at $10 \mathrm{~min} / \mathrm{GTP}$ at $0 \mathrm{~min}) \times 100$. The point at $0 \mathrm{ng}$ reflects the intrinsic rate of GTP hydrolysis. Data is presented as the mean of triplicate samples from three experiments \pm S.D.

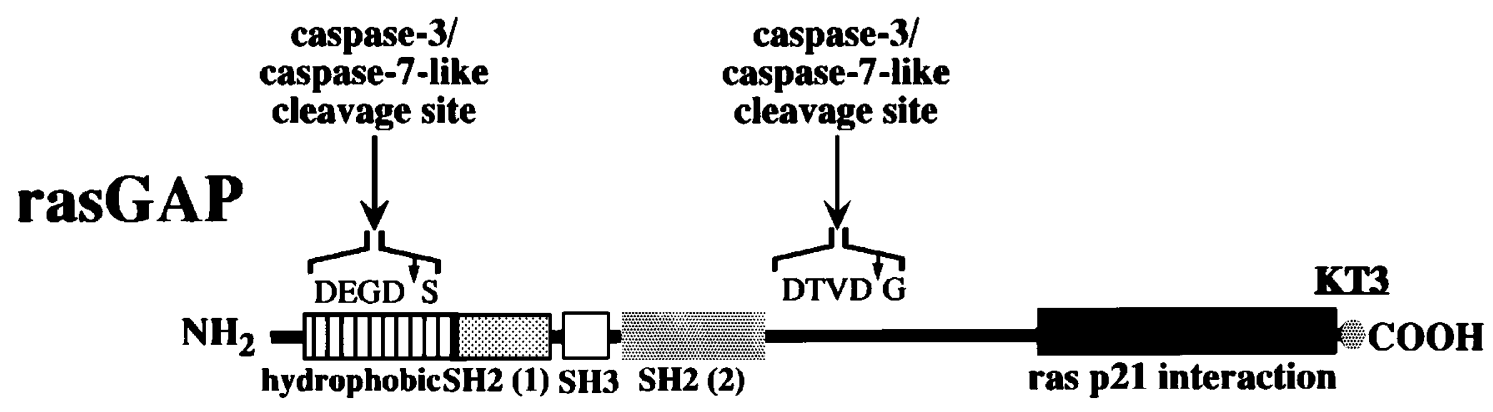

Figure 5 Predicted cleavage sites in rasGAP. A schematic of rasGAP with the predicted cleavage sites in its hydrophobic domain and between the SH2 (2) and ras $\mathrm{p} 21$-interacting domains are shown 
function for rasGAP demonstrating that rasGAP inhibits GDP/GTP exchange factor (GEF) activity in vitro (Giglione et al, 1997). GEF plays an important role in modulating GDP/GTP exchange on Ha-Ras. These studies in addition to the recent observation that disruption of rasGAP results in neuronal apoptosis in vivo suggest that rasGAP may play a key role in coordinating signal transduction pathways that regulate cell survival.

Apoptosis results in the activation of caspases and the disruption of many cellular substrates that are important for maintaining nuclear and cytoplasmic integrity. We show here that rasGAP is cleaved by caspases early in Fasinduced apoptosis of Jurkat cells. Moreover, we observed that rasGAP was cleaved by Fas in other cell lines and by other apoptotic stimuli such as chemotherapy and TRAIL. Gulbins et al, recently demonstrated that Fas-induced apoptosis of Jurkat cells may be mediated by a Ras signaling pathway but they did not detect a change in rasGAP activity minutes after the addition of Fas (Gulbins et al, 1995). We observed sequential cleavage of rasGAP in Fas-treated Jurkat cells which we preliminary mapped, based on the size of the cleavage products and the location of the DXXD motifs, to the hydrophobic region and the region between the $\mathrm{SH} 2(2)$ and ras-p21 interacting domain in rasGAP. Cleavage of rasGAP in its hydrophobic region is detected first followed by the cleavage between the $\mathrm{SH} 2(2)$ and ras-p21-interacting domain. This pattern of cleavage leaves an intact ras-p21 interacting but cleaved rasGAP is more active in vitro than uncleaved rasGAP in catalyzing the hydrolysis of GTP-Ras to GDP-Ras. We do not yet know the functional significance of rasGAP cleavage in vivo but our observation that rasGAP is cleaved early in apoptosis by diverse apoptotic stimuli and that cleavage of rasGAP enhances hydrolysis of Ras coupled with a recent study which shows that disruption of rasGAP causes apoptosis in vivo suggest that cleavage of rasGAP may play a role in the activation of apoptotic signaling pathways and the inactivation of growth stimulatory pathways. It will be important to mutate the cleavage sites in rasGAP and then examine the effect on apoptosis in vivo.

\section{Materials and Methods}

\section{Cell culture}

The Jurkat $\mathrm{T}$ cell line and $\mathrm{H} 460$ lung cancer cell lines were purchased from ATCC (Rockville, MD). Jurkat cells were cultured in RPMI and H460 cells in DMEM with $10 \%$ FCS supplemented with L-glutamine, penicillin and streptomycin.

\section{Cell death reagents and assays}

Anti-Fas (IgM) mAb, clone $\mathrm{CH}-11$, was purchased from Medical and Biological Laboratories (Nagoya, Japan) and used at a concentration of $100 \mathrm{ng} / \mathrm{ml}$. TRAIL (Apo2L) was a gift from Dr. Avi Ashkenazi, Genentech, South San Francisco. Doxorubicin and taxol were provided by Dr. Branimir Sikic, Stanford University. Cell death was determined with the ApoAlert Annexin V Apoptosis Kit from Clontech (Palo Alto, CA) according to the manufacturer's protocol. After the cells were incubated with Annexin V-FITC $(1 \mu \mathrm{g} / \mathrm{ml})$ they were analyzed by FACS analysis. The tetrapeptide caspase inhibitors DEVD-CHO and YVAD-CHO were purchased from BACHEM (Torrance, $\mathrm{CA}$ ). For in vivo studies with the caspase inhibitors, DEVD-CHO $(200 \mu \mathrm{M})$ or YVAD-CHO $(200 \mu \mathrm{M})$ were added to cells $1 \mathrm{~h}$ prior to the addition of the anti-Fas $m A b$.

\section{Antibodies and Western blot analysis}

An anti-rasGAP mAb was purchased from Santa Cruz Biotechnology (Santa Cruz, CA). The anti-KT3 antibody is directed against the epitope tag at the carboxyl terminus of purified rasGAP (Martin et al, 1990). Purified rasGAP and deletion mutants of rasGAP were prepared as described (Martin et al, 1992). For immunoblot analysis, Jurkat cells were treated with the $\mathrm{CH}-11$ anti-Fas $\mathrm{mAb}$ and then processed for immunoblotting as described previously (Wen et al, 1997).

\section{Preparation of naive extracts}

Jurkat cells were washed with ice-cold PBS, and then resuspended in hypotonic buffer (10 mM Tris- $\mathrm{HCl}, \mathrm{pH} 7.5,20 \mathrm{mM} \mathrm{KCl}, 1 \mathrm{mM}$ DTT, and $0.1 \mathrm{mM}$ PMSF) and left on ice for $30 \mathrm{~min}$. Cells were then lysed with 20 strokes of a Dounce homogenizer (type B pestle) and centrifuged at maximum speed for $20 \mathrm{~min}$ at $4^{\circ} \mathrm{C}$. Supernatants (naive and apoptotic extracts) were divided into small aliquots and stored at $-80^{\circ} \mathrm{C}$ until use.

\section{In vitro cleavage with purified caspases}

One $\mu \mathrm{g}$ of purified Ras GAP was incubated with the indicated amount of purified caspases in the presence or absence of naive Jurkat cellular extract and placed in cleavage buffer $(10 \mathrm{mM}$ Tris-HCl, $\mathrm{pH} 7.5$, $50 \mathrm{mM} \mathrm{KCl}, 2 \mathrm{mM} \mathrm{MgCl}$, and $1 \mathrm{mM} \mathrm{DTT}$ ) at $37^{\circ} \mathrm{C}$ for $1 \mathrm{~h}$, separated on a $10 \%$ SDS gel, and immunoblotted with the rasGAP $m A B$ from Santa Cruz or the $\alpha \mathrm{KT} 3$ antibody. The purified caspases were provided by Guy Salvesen, Burnham Institute (La Jolla, CA). The activity of the caspases was determined by $\mathrm{Dr}$. Salvesen with an affinity labeled AcAsp-Glu-Val-fluromethyl ketone (Ac-DEVD-fmk) (a gift of Joe Krebbs, IDUN Pharmaceuticals). The caspases were titrated with a known amount of the affinity reagent, followed by analysis of residual activity using the caspase substrate Ac-DEVD-p-Nitroanailide (Alexis Corp., San Diego, CA).

\section{rasGAP activity assay}

A filter-binding rasGAP assay was performed essentially as described but with some modifications (Bollag and McCormick, 1995). Purified rasGAP (125-375 $\mathrm{ng}$ ) was incubated in the presence or absence of caspase-3 (200 ng) in cleavage buffer at $37^{\circ} \mathrm{C}$ for $1 \mathrm{~h}$. One-half of both samples was used for Western blot analysis with the $\alpha \mathrm{KT} 3$ antibody and confirmed that rasGAP was cleaved. The other half of the cleaved and uncleaved rasGAP samples was combined with the Ras-GTP loading reaction containing $1 \mu \mathrm{l}$ of purified K-Ras $(1 \mu \mathrm{g}), 10 \mu \mathrm{L}$ of GTP loading buffer (1 mM EDTA, 20 mM HEPES (pH 7.3), 2 mM DTT and $1 \mu \mathrm{l}$ of $\gamma-{ }^{32} \mathrm{P}$-GTP and the mixture was incubated at RT for $10 \mathrm{~min}$. The reactions was then divided equally for three GTP-hydrolysis reactions which contained: (1) $10 \mu \mathrm{l}$ of cleaved rasGAP plus $40 \mu \mathrm{l}$ of buffer $\mathrm{B}$ (20 mM HEPES (pH 7.3), $2 \mathrm{mM} \mathrm{MgCl} 2,2 \mathrm{mM} \mathrm{DTT}$ ) and $4 \mu \mathrm{l}$ of the Ras-GTP loading mix; or (2) $10 \mu \mathrm{l}$ of uncleaved rasGAP plus $40 \mu \mathrm{l}$ of buffer B and $4 \mu \mathrm{l}$ of Ras-GTP loading mix; or (3) $10 \mu$ l of cleavage buffer plus $40 \mu \mathrm{l}$ of buffer B and $4 \mu \mathrm{l}$ of Ras-GTP loading mix. The samples were incubated at room temperature for $10 \mathrm{~min}$. Samples 
were diluted in $1 \mathrm{ml}$ of wash buffer ( $20 \mathrm{mM}$ Tris $(\mathrm{pH} 8.0), 100 \mathrm{mM}$ $\mathrm{NaCl}, 5 \mathrm{mM} \mathrm{MgCl} 2$ ), placed on $0.45 \mu \mathrm{M}$ nitrocellulose filters (Amersham, Arlington Heights, IL) and washed two times with $7 \mathrm{~m}$ of wash buffer. The samples were quantitated by Cerenkov counting.

\section{Acknowledgements}

We thank Guiyan Xu for technical assistance. We would like to thank Avi Ashkenazi for TRAIL/Apo2L and Branimir Sikic for doxorubicin and taxol. We are very grateful to Guy Salvesen for providing purified caspases and for helpful discussions. This work was supported in part by a grant from the Program in Molecular and Genetic Medicine at Stanford University.

\section{References}

Bollag G and McCormick F (1991) Differential regulation of rasGAP and neurofibromatosis gene product activities. Nature 351: 576-579

Bollag $G$ and McCormick F (1995) Intrinsic and GTPase-activating proteinstimulated Ras GTPase assays. Methods Enzymol 255: 161-170

Brancolini C, Benedetti M and Schneider C (1995) Microfilament reorganization during apoptosis: the role of Gas2, a possible substrate for ICE-like proteases. Embo J. 14: 5179-5190

Casciola-Rosen L, Nicholson DW, Chong T, Rowan KR, Thornberry NA, Miller DK and Rosen A (1996) Apopain/CPP32 cleaves proteins that are essential for cellular repair: a fundamental principle of apoptotic death (see comments). J. Exp. Med. 183: 1957-1964

Chinnaiyan AM, Orth K, O'Rourke K, Duan H, Poirier GG and Dixit VM (1996) Molecular Ordering of the Cell Death Pathway. J. Biol. Chem. 271: 4573-4576

Dixit VM (1996) Role of ICE-proteases in apoptosis. Adv. Exp. Med. Biol. 406: 113117

Ellis C, Moran M, McCormick F and Pawson T (1990) Phosphorylation of GAP and GAP-associated proteins by transforming and mitogenic tyrosine kinases. Nature 343: 377-381

Emoto Y, Manome Y, Meinhardt G, Kisaki H, Kharbanda S, Robertson M, Ghayur T, Wong WW, Kamen R, Weichselbaum R and Kufe D. (1995) Proteolytic activation of protein kinase $C$ delta by an ICE-like protease in apoptotic cells. Embo J. 14 6148-6156

Ferrari G and Greene LA (1994) Proliferative inhibition by dominant-negative Ras rescues naive and neuronally differentiated PC12 cells from apoptotic death. Embo J. 13: 5922-5928

Giglione C, Parrini MC, Baouz S, Bernardi A and Parmeggiani A (1997) A new function of p120-GTPase-activating protein. Prevention of the guanine nucleotide exchange factor-stimulated nucleotide exchange on the active form of Ha-ras p21. J. Biol. Chem. 272: 25128-25134

Gulbins E, Bissonnette R, Mahboubi A, Martin S, Nishioka W, Brunner T, Baier G, Baier-Bittertlich G, Byrd C, Lang F, Kolesnick R, Altman A and Green D. (1995) Fas-induced apoptosis is mediated via a ceramide-initiated RAS signaling pathway. Immunity 2: 341-351

Gulbins E, Coggeshall KM, Brenner B, Schlottmann K, Linderkamp O and Lang F (1996) Fas-induced apoptosis is mediated by activation of a Ras and Rac proteinregulated signaling pathway. J. Biol. Chem. 271: 26389-26394

Henkemeyer M, Rossi DJ, Holmyard DP, Puri MC, Mbamalu G, Harpal K, Shih TS, Jacks T and Pawson T(1995) Vascular system defects and neuronal apoptosis in mice lacking ras GTPase-activating protein. Nature 377: 695-701

Itoh N, Yonehara S, Ishii A, Yonehara M, Mizushima S, Sameshima M, Hase A, Seto Y and Nagata $S$ (1991) The polypeptide encoded by the cDNA for human cell surface antigen Fas can mediate apoptosis. Cell 66: 233-243

Kazlauskas A, Ellis C, Pawson T and Cooper JA (1990) Binding of GAP to activated PDGF receptors. Science 247: 1578-1581
Lazebnik YA, Kaufmann SH, Desnoyers S, Poirier GG and Earnshaw WC (1994) Cleavage of poly(ADP-ribose) polymerase by a proteinase with properties like ICE. Nature 371: $346-347$

Martin GA, Viskochil D, Bollag G, McCabe PC, Crosier WJ, Haubruck H, Conroy L, Clark R, O'Connell P and Cawthon RM (1990) The GAP-related domain of the neurofibromatosis type 1 gene product interacts with ras p21. Cell 63: 843-849

Martin GA, Yatani A, Clark R, Conroy L, Polakis P, Brown AM and McCormickF (1992) GAP domains responsible for ras p21-dependent inhibition of muscarinic atrial K+ channel currents (see comments). Science 255: 192-194

McCormick F (1994) Activators and effectors of ras p21 proteins. Curr. Opin. Genet. Dev. 4: 71-76

Moran MF, Polakis P, McCormick F, Pawson T and Ellis C (1991) Protein-tyrosine kinases regulate the phosphorylation, protein interactions, subcellular distribution, and activity of p21ras GTPase-activating protein. Mol. Cell. Biol. 11: $1804-1812$

Na S, Chuang TH, Cunningham A, Turi TG, Hanke JH, Bokoch GM and Danley DE (1996) D4-GDI, a substrate of CPP32, is proteolyzed during Fas-induced apoptosis. J. Biol. Chem. 271: 11209-11213

Nicholson DW, Ali A, Thornberry NA, Vaillancourt JP, Ding CK, Gallant M, Gareau Y, Griffin PR, Labelle M, Lazebnik YA, Munday NA, Raju SM, Smalson ME, Yamin TT, Yu VL and Miller DK. (1995) Identification and inhibition of the ICE/CED-3 protease necessary formammalian apoptosis (see comments). Nature 376:3743

Ridley AJ and Hall A (1992) The small GTP-binding protein rho regulates the assembly of focal adhesions and actin stress fibers in response to growth factors. Cell 70: 389-399

Settleman J, Narasimhan V, Foster LC and Weinberg RA (1992) Molecular cloning of cDNAs encoding the GAP-associated protein $\mathrm{p} 190$ : implications for a signaling pathway from ras to the nucleus. Cell 69: 539-549

Song Q, Lees-Miller SP, Kumar S, Zhang Z, Chan DW, Smith GC, Jackson SP, AlnemriES, Litwack G, Khanna KK and Lavin MF (1996) DNA-dependentprotein kinase catalytic subunit: a target for an ICE-like protease in apoptosis. Embo J. 15: $3238-3246$

Srinivasula SM, Ahmad M, Fernandes-Alnemri T, Litwack G and Alnemri ES (1996) Molecular ordering of the Fas-apoptotic pathway: the Fas/APO-1 protease Mch5 is a CrmA-inhibitable protease that activates multiple Ced-3/ICE-like cysteine proteases. Proc. Natl. Acad.Sci. USA 93: 14486-14491

StellerH (1995) Mechanisms and genes of cellular suicide. Science 267: 1445-1449

Talanian RV, Quinlan C, Trautz S, Hackett MC, Mankovich JA, Banach D, Ghayur T, Brady KD and Wong WW (1997) Substrate specificities of caspase family proteases. J. Biol. Chem. 272: 9677-9682

Trayey M, Wong G, Halenbeck R, Rubinfeld B, Martin GA, Ladner M, Long CM, Crosier WJ, Watt K, Koths K and McCormick F (1988) Molecular cloning of two types of GAP complementary DNA from human placenta. Science 242: 16971700

Wang HG, Millan JA, Cox AD, Der CJ, Rapp UR, Beck T, Zha H and Reed JC (1995)RRas promotes apoptosis caused by growth factor deprivation via a Bcl-2 suppressible mechanism. J. Cell. Biol. 129: 1103-1114

Wang X, Zelenski NG, Yang J, Sakai J, Brown MS and Goldstein JL (1996) Cleavage of sterol regulatory element binding proteins (SREBPs) by CPP32 during apoptosis. Embo J. 15: 1012-1020

Waterhouse N, Kumar S, Song Q, Strike P, Sparrow L, Dreyfuss G, Alnemri ES, Litwack G, Lavin M and Watters D (1996) Heteronuclear ribonucleoproteins C1 and $\mathrm{C} 2$, components of the spliceosome, are specific targets of interleukin 1betaconverting enzyme-like proteases in apoptosis. J. Biol. Chem. 271: 2933529341

Wen LP, Fahrni JA, Troie S, Guan JL, Orth K and Rosen GD (1997) Cleavage of focal adhesion kinase by caspases during apoptosis (In Process Citation). J. Biol. Chem. 272: 26056-26061 